\title{
Evaluation of the impact of radical tumor resection in lung cancer patients on the activity of selected antioxidant enzymes
}

\author{
Piotr Misiak, Beata Rzepkowska-Misiak, Szymon Wcisło, Katarzyna Dziwińska, Katarzyna Malinowska, \\ Ireneusz Majsterek
}

Military Medical Academy University Teaching Hospital - Central Veterans' Hospital in Łódź, Łódź, Poland

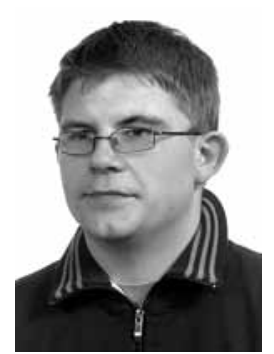

Kardiochirurgia i Torakochirurgia Polska 2014; 11 (4): 414-420

\begin{abstract}
Introduction: Oxidative stress appears to play an essential role as a secondary messenger in such physiological processes as apoptosis and survival as well as in proliferative signaling pathways. Oxidative damage is also considered to play a pivotal role in ageing, several degenerative diseases, and carcinogenesis. Lung cancer is the most common type of cancer, resulting in over 1.3 million deaths each year worldwide.

Aim: The aim of this study was to evaluate the activity of selected antioxidative enzymes in patients with lung cancer before and after radical surgery.

Material and methods: The study included 20 patients in the study group and 10 healthy volunteers in the control group. In the study group, blood samples were collected twice: one day before and one day after the operation. In the control group, blood samples were collected once. We estimated the activity of catalase (CAT), glutathione peroxidase (GPX), and superoxide dismutase (SOD) in erythrocytes. The total antioxidant status in blood plasma was also determined.

Results: The activity of the selected antioxidative enzymes was greater in the case of GPX and CAT after surgery; the results were statistically significant in the study group. The activity of SOD remained at a comparable level. The total antioxidant status also increased after surgery in the study group in comparison to its preoperative level.
\end{abstract}

Key words: lung cancer, oxidative stress, antioxidant enzymes.

\section{Introduction}

Lung cancer is the most frequent malignant neoplasm, causing approximately 1.3 million deaths each year worldwide. It is also associated with one of the poorest prognoses among all types of cancer, with 5-year survival rates of about $12 \%$ for men and $17 \%$ for women.

\section{Streszczenie}

Wstęp: Stres oksydacyjny wydaje się odgrywać znaczącą rolę jako wtórny przekaźnik sygnałowy w takich procesach fizjologicznych, jak apoptoza i przeżycie, jak również w proliferacyjnych szlakach sygnałowych. Uszkodzenia oksydacyjne są również uznawane za kluczowe w procesie starzenia się, niektórych chorobach zwyrodnieniowych oraz kancerogenezie. Rak płuc jest najczęstszym nowotworem złośliwym, powodującym co roku śmierć 1,3 miliona osób na całym świecie.

Cel: Określenie aktywności wybranych enzymów antyoksydacyjnych u pacjentów z rakiem płuc przed i po radykalnym zabiegu operacyjnym.

Materiał i metody: Badaniem objęto grupę 20 pacjentów (grupa badana) oraz 10 zdrowych ochotników (grupa kontrolna). W grupie badanej próbki krwi pobrano dwukrotnie - dzień przed operacją i dzień po operacji. W grupie kontrolnej krew pobrano raz. Oceniono aktywność katalazy (catalase - CAT), peroksydazy glutationowej (glutathione peroxidase GPX) i dysmutazy nadtlenowej (superoxide dismutase - SOD) w erytrocytach. Określono również ogólny status antyoksydacyjny w osoczu.

Wyniki: Aktywność wybranych enzymów antyoksydacyjnych była wyższa przed operacją w przypadku GPX oraz CAT; wyniki w badanej grupie były istotne statystycznie. Aktywność SOD utrzymywała się na podobnym poziomie. Ogólny status antyoksydacyjny w badanej grupie również wzrósł po operacji w porównaniu z poziomem stwierdzonym przed operacją. Słowa kluczowe: rak płuc, stres oksydacyjny, enzymy antyoksydacyjne.

Malignant neoplasms are the second leading cause of death in Poland, being responsible for $26 \%$ of deaths among men and 23\% among women. In 2011, 144 thousand new cases of malignant neoplasms were reported in Poland, approximately 20 thousand of which were newly identified cases of lung cancer. 
Due to the high percentage of tobacco smokers (about $41 \%$ of men and $19 \%$ of women), high levels of environmental pollution arising from heavy industrialization, as well as the demographic and economic situation of the region, in terms of morbidity (based on the standardized morbidity rate), the tódź voivodeship occupied the $4^{\text {th }}$ position for the female population (approximately 550 new cases) and the $7^{\text {th }}$ position for the male population (with approximately 1000 new cases) in 2011 (on a national scale). In terms of mortality, based on the standardized mortality rate, the positions were the following: $8^{\text {th }}$ for the female population (approximately 460 deaths) and $9^{\text {th }}$ for the male population (approximately 1100 deaths). Since 2007, a trend has been visible in Poland each year where the number of lung cancer deaths among women has exceeded the number of deaths due to breast cancer (in spite of the opposite trend in the morbidity structure).

According to the current state of scientific knowledge, long-term exposure to inhaled carcinogens, especially tobacco smoke, is associated with the highest risk of lung cancer. It seems that, in the rare cases of lung cancer among non-smokers, a combination of genetic factors, passive smoking, and environmental pollution may constitute the cause.

Inhaling quartz, metal powders, mineral asbestos fibers, ozone, gasoline and diesel engine fumes, and particulate matter $\left(\mathrm{PM}_{10}, \mathrm{PM}_{2,5}\right)$ is especially significant in this process.

All these factors result in higher levels of reactive oxygen and nitrogen species (ROS and RNS) and increased oxidative stress in the respiratory system. This may lead to the overproduction of pulmonary inflammation mediators and the initiation or promotion of carcinogenesis. The initiation and promotion of pulmonary cancer has been linked to a series of biochemical pathways of oxidative stress. All aerobic organisms have evolved antioxidant defenses to protect themselves against ROS and RNS generated in vivo. The most important antioxidant enzymes are superoxide dismutase (SOD), catalase (CAT), and glutathione peroxidase (GPX).

The aim of this study is to evaluate the activity of selected antioxidative enzymes in patients with lung cancer before and after radical surgery.

A better understanding of the exact role and alteration of antioxidant profiles in lung cancer may contribute to the future use of antioxidants in the management of lung cancer.

\section{Material and methods}

In the years 2012-2013, we enrolled and operated on 20 patients with non-small cell lung cancer (NSCLC) in clinical stages I (9 patients) and II (11 patients). The lesion was right-sided in 9 cases and left-sided in 11. The study group included 11 men and 9 women. Their ages ranged from 53 to 74 (mean: 61.9) (Table I). The control group consisted of healthy volunteers: 9 men and 1 woman. Their ages ranged from 24 to 79 (mean: 42.9) (Table II). All patients in the study group were ex-smokers suffering from NSCLC, qualified for lobectomy due to the stage of their disease. All patients were qualified for the surgical procedures after

Tab. I. Characteristics of the study group

\begin{tabular}{|c|c|c|c|c|c|c|c|c|}
\hline Variable & $N$ & Mean & Median & Min & Max & Q25 & Q75 & SD \\
\hline Age & 20 & 61.90 & 62.50 & 53.00 & 74.00 & 57.50 & 65.00 & 5.63 \\
\hline Height & 20 & 166.75 & 165.00 & 152.0 & 190.00 & 159.50 & 172.50 & 9.39 \\
\hline Weight & 20 & 68.150 & 68.00 & 45.00 & 91.00 & 59.50 & 78.00 & 13.33 \\
\hline BMI & 20 & 24.25 & 25.25 & 17.36 & 32.00 & 20.83 & 26.55 & 3.94 \\
\hline & \multicolumn{4}{|c|}{ Male } & \multicolumn{4}{|c|}{ Female } \\
\hline \multirow[t]{2}{*}{ Gender } & & & \multicolumn{2}{|c|}{$\%$} & \multicolumn{2}{|c|}{$n$} & \multicolumn{2}{|r|}{$\%$} \\
\hline & \multicolumn{2}{|c|}{11} & \multicolumn{2}{|c|}{55} & \multicolumn{2}{|c|}{9} & \multicolumn{2}{|r|}{45} \\
\hline
\end{tabular}

BMI - body mass index

Tab. II. Characteristics of the control group

\begin{tabular}{|c|c|c|c|c|c|c|c|c|c|}
\hline Variable & $N$ & & Mean & Median & Min & $\operatorname{Max}$ & Q25 & Q75 & SD \\
\hline Age & 10 & & 42.90 & 43.00 & 24.00 & 79.00 & 28.00 & 46.00 & 17.00 \\
\hline Height & 10 & & 170.80 & 170.00 & 167.00 & 179.00 & 168.00 & 172.00 & 3.43 \\
\hline Weight & 10 & & 72.70 & 74.50 & 55.00 & 98.00 & 57.00 & 81.00 & 13.61 \\
\hline BMI & 10 & & 24.98 & 25.34 & 19.30 & 35.14 & 20.20 & 27.40 & 4.88 \\
\hline & & \multicolumn{3}{|c|}{ Male } & \multicolumn{5}{|c|}{ Female } \\
\hline \multirow[t]{2}{*}{ Gender } & & $n$ & & \multicolumn{2}{|c|}{$\%$} & \multicolumn{2}{|r|}{$n$} & \multicolumn{2}{|l|}{$\%$} \\
\hline & & 9 & & \multicolumn{2}{|c|}{90} & \multicolumn{2}{|r|}{1} & \multicolumn{2}{|l|}{10} \\
\hline
\end{tabular}

BMI - body mass index 
providing formal consent. They were operated on under general anesthesia with one-lung ventilation. Blood samples were taken twice in the study group (one day before the operation and one day after the operation) and once in the control group.

\section{Blood sample preparation}

Venous blood $(5 \mathrm{ml})$ in lithium heparin was taken from each lung cancer patient (twice) and from each member of the control group (once). Red blood cells were separated from plasma and buffy coat by immediate centrifugation at $3500 \mathrm{r} / \mathrm{min}$ for $10 \mathrm{~min}$ and stored at $-70^{\circ} \mathrm{C}$ for the subsequent assays of antioxidants activity. Red blood cell lysate was prepared by washing packed red blood cells three times with cold normal saline under centrifugation at $3500 \mathrm{r} / \mathrm{min}$.

\section{Hemoglobin assay}

For the purpose of determining enzyme activity, hemoglobin $(\mathrm{Hb})$ concentration in erythrocyte hemolysate was estimated at $540 \mathrm{~nm}$ using a spectrometer (UV/VIS Spectrometer Lambda 14P, Perkin Elmer, USA) after conversion into cyanmethemoglobin with Drabkin's reagent (AquaMed, Poland) [1].

\section{Catalase activity}

Catalase activity in erythrocytes was determined according to the spectrophotometric procedure described by Beers and Sizer (1952) [2] and calculated in Bergmeyer units (BU/g Hb). Catalase activity was measured at $240 \mathrm{~nm}$ with a spectrometer at $25^{\circ} \mathrm{C}$ by recording $\mathrm{H}_{2} \mathrm{O}_{2}$ decomposition (UV/VIS Spectrometer Lambda 14P, Perkin Elmer, USA). One Bergmeyer unit (BU) of this activity is defined as the amount of enzyme decomposing $1 \mathrm{~g}$ of $\mathrm{H}_{2} \mathrm{O}_{2}$ per min.

\section{Glutathione peroxidase activity}

Glutathione peroxidase activity in erythrocytes was measured according to the spectrophotometric procedure described by Little and O'Brien (1952) [3] and presented as enzymatic units $(\mathrm{U} / \mathrm{g} \mathrm{Hb})$. The difference in the rate of GPX reaction with glutathione and cumene in the acquired samples is used for determining its activity by measuring absorbance with a spectrometer (UV/VIS Spectrometer Lambda 14P, Perkin Elmer, USA) at $412 \mathrm{~nm}$. One unit of GPX activity is calculated as the amount of enzyme which causes a $10 \%$ decrease in the level of reduced glutathione within $1 \mathrm{~min}$ at $25^{\circ} \mathrm{C}, \mathrm{pH}$ 7.0.

\section{Superoxide dismutase activity}

Superoxide dismutase activity in erythrocytes was measured according to the procedure described by Misra and Fridovich (1972) [4] and expressed in adrenaline units (U/g Hb/100 ml). SOD activity was determined by absorbance increase at $480 \mathrm{~nm}$ with a spectrometer at $37^{\circ} \mathrm{C}$ (UV/ VIS Spectrometer Lambda 14P, Perkin Elmer, USA) followed by the auto-oxidation of adrenaline inhibited by CUZn-SOD.
One unit of SOD activity is defined as the amount of enzyme inhibiting adrenaline auto-oxidation at $50 \%$.

\section{Total antioxidant status determination}

Total antioxidant status in blood plasma was determined using the spectrophotometric method applied according to procedure no. NX2332 by Randox (Randox Laboratories Ltd. Ardmore, Diamond Road, Crumlin, Co Antrim, United Kingdom, BT29 4QY). In short, ABTS (2,2-azino-di[3ethylbenzthiazoline sulfonate]) was incubated with peroxide (metmyoglobin) and $\mathrm{H}_{2} \mathrm{O}_{2}$ to produce a ABTS radical cation with relatively stable blue-green color. Antioxidants, when added to the examined sample, suppressed the production of this color, which was measured as absorbance decrease using a spectrometer (UV/VIS Spectrometer Lambda 14P, Perkin Elmer, USA) at $600 \mathrm{~nm}$. The total antioxidant status was calculated as the concentration of antioxidants (mmol/l).

\section{Statistical analysis}

Basic demographic data are expressed as mean, SD, median, and interquartile range.

Statistical analysis was performed using the Statistica ver. 6.0 software. The statistical analysis included the following: Student's $t$-test, Wilcoxon test, $\chi^{2}$, and Spearman's rank correlation coefficient. A $p$-value $<0.05$ was considered to be of statistical significance.

\section{Results}

The activity of SOD, CAT, GPX, and TAS was determined in both the control group and the study group. Graphical analysis of the selected parameters in both groups before surgery is shown in Figures 1-4. The characteristics of the activity of individual antioxidative enzymes in the control group are presented in Table III, while the data for the study group are presented in Table IV. Lower activity of antioxidative enzymes was found in the study group prior to surgery in comparison to the control group, but only the differences in the CAT activity (11.45 [5.20-29.17] in the study group vs. 19.8 [15.60-24.00] in controls) and TAS (1.29 [0.92-1.86] in the study group vs. 1.67 [1.19-1.80] in controls) were statistically significant (Table V). Statistically lower initial CAT activity and TAS were demonstrated in lung cancer patients in comparison to the group of healthy subjects. The difference in enzymatic activity after the operation between the study group and the control group was statistically insignificant (Table VI). A statistically significant increase in GPX (52.13 [27.51-97.75] vs. 58.16 [29.32-78]) and CAT activity (11.45 [5.20-29.17] vs. 14.86 [6.40-38.47]) as well as TAS (1.29 [0.92$1.86]$ vs. 1.53 [0.92-2.6]) was noted in the study group after the operation. A statistically significant increase of SOD activity was not observed (1435.27 vs. 1483.98) (Table VII). The changes in the above-listed parameters are presented in Figures 5-8. With the use of Spearman's rank correlation coefficient, the study group was tested for the relationship between enzyme activity (measured before and after 


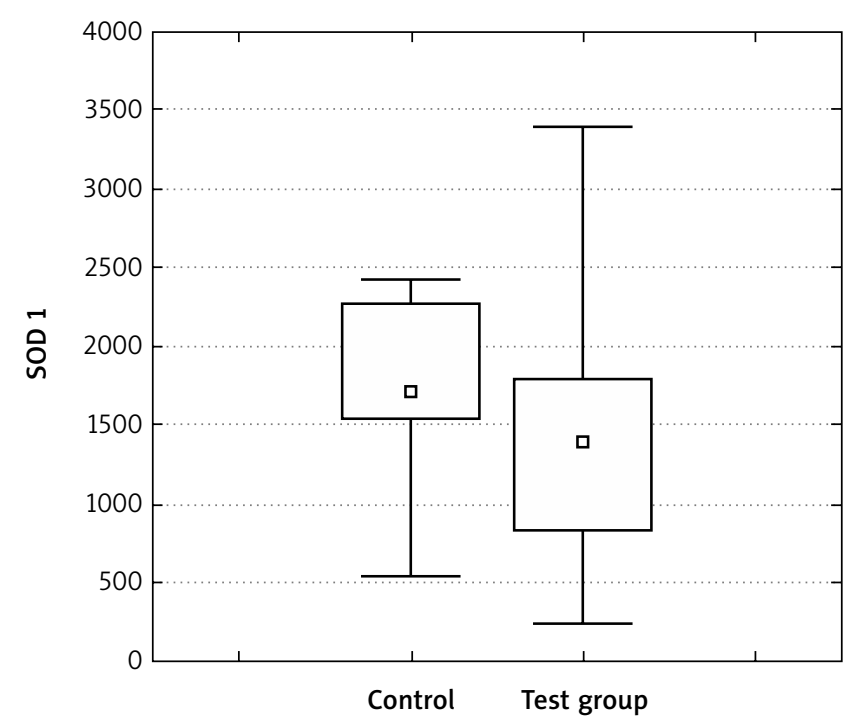

- Mediana $\square 25 \%-75 \% \quad$ IMin.-Maks

Fig. 1. Superoxide dismutase in the control and study groups before surgery

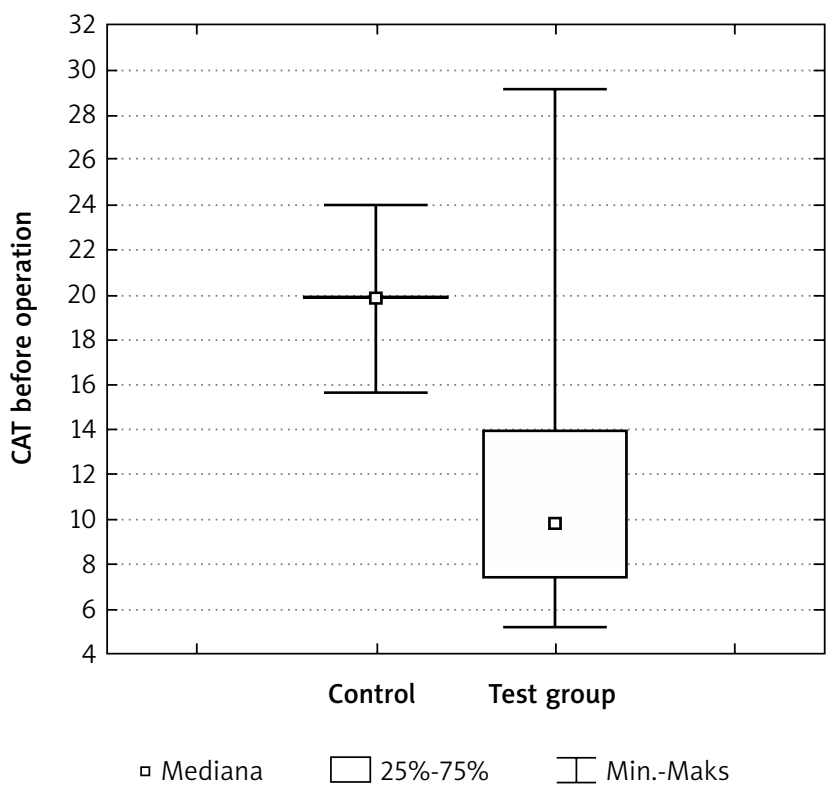

Fig. 3. Catalase in the control and study groups before surgery

surgery) and age, height, and BMI index, but no statistically significant correlation between these parameters was found.

\section{Discussion}

Each day, our lungs are exposed to various oxidants of either endogenous or exogenous origin, especially air pollutants and cigarette smoke. Cigarette smoke is a complex aerosol that consists of thousands of chemical compounds, some of which have been identified as carcinogens. Numerous studies have shown that smoking cigarettes is associated with inflammation and oxidative stress. Tobacco smoke, which contains $10^{14}$ ROS and 700 ppm NO per puff

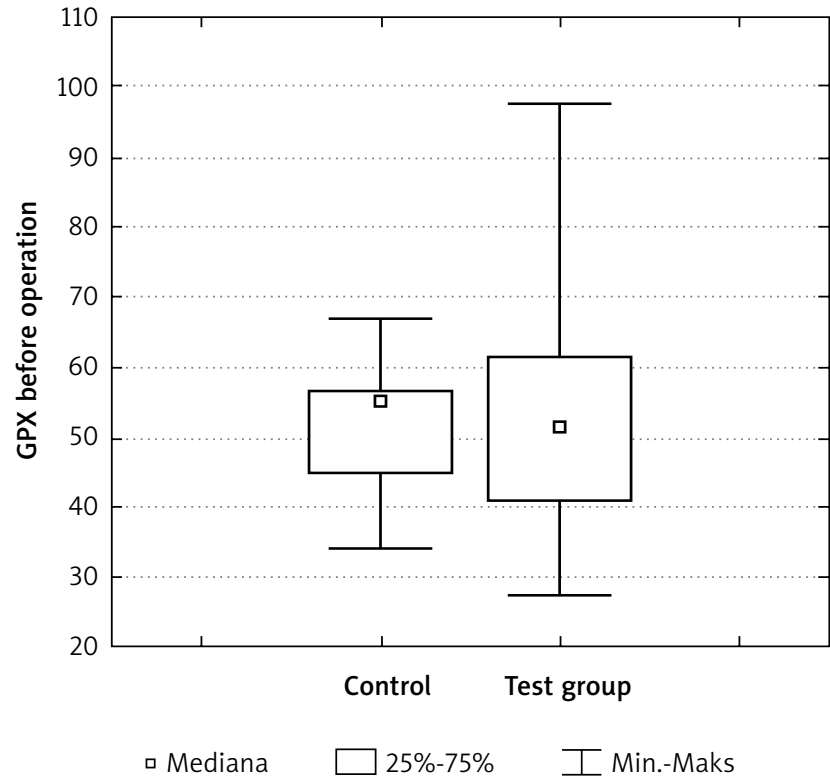

Fig. 2. Glutathione peroxidase in the control and study groups before surgery

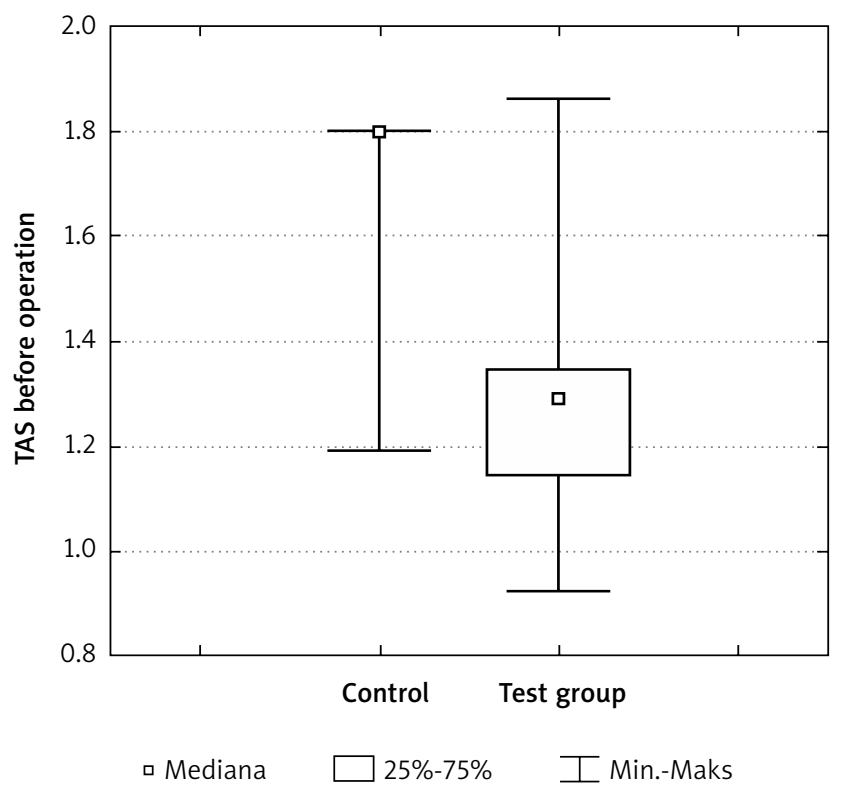

Fig. 4. Total antioxidant status in the control and study groups before surgery

[5], is the main cause of lung cancer; in the USA it is responsible for almost $87 \%$ of cases [5]. In developing countries, it remains the leading cause of cancer mortality, which is also the case in Poland [6]. The risk increases with the time of smoking and the daily amount of tobacco used. Cigarette smoke leads to chronic airway inflammation with the accumulation and activation of leukocytes, neutrophils, and macrophages, which play a pivotal role in the regional and systemic effects of oxidative stress $[5,7,8]$. After activation, leukocytes and neutrophils produce high levels of reactive oxygen (ROS) and nitrogen species (RNS). Resident macrophages in the airways can release ROS/RNS after the phagocytosis of the inhaled particles, as well as releasing 
Tab. III. Quantitative characteristics of the enzymatic activity in the control group

\begin{tabular}{lccccccccc} 
Variable & $N$ & Mean & Median & Min & Max & Q25 & Q75 & SD \\
SOD & 10 & 1782.300 & 1704.500 & 540.000 & 2430.00 & 1550.00 & 2269.00 & 550.78 \\
\hline GPX & 10 & 52.60000 & 55.00000 & 34.0000 & 66.9000 & 45.0000 & 56.7000 & 9.240 \\
\hline CAT & 10 & 19.80000 & 19.80000 & 15.600 & 24.00 & 19.800 & 19.80 & 1.98 \\
\hline TAS & 10 & 1.679000 & 1.800000 & 1.1900 & 1.8000 & 1.8000 & 1.800 & 0.26 \\
\hline
\end{tabular}

SOD - superoxide dismutase, GPX - glutathione peroxidase, CAT - catalase, TAS - total antioxidant status

Tab. IV. Quantitative characteristics of the enzymatic activity in the study group

\begin{tabular}{lcccccccc} 
Variable & $N$ & Mean & Median & Min & Max & Q25 & Q75 & SD \\
SOD before operation & 20 & 1435.275 & 1392.500 & 243.00 & 3400.0 & 835.50 & 1802.0 & 832.26 \\
\hline SOD after operation & 20 & 1483.985 & 1317.00 & 158.00 & 3566.70 & 1023.00 & 2099.00 & 868.65 \\
\hline GPX before operation & 20 & 52.13500 & 51.45000 & 27.51 & 97.75 & 40.95 & 61.45 & 16.48 \\
\hline GPX after operation & 20 & 58.16050 & 57.95000 & 29.320 & 78.00 & 55.00 & 67.90 & 12.98 \\
\hline CAT before operation & 20 & 11.45550 & 9.750000 & 5.20 & 29.17 & 7.40 & 13.95 & 5.84 \\
\hline CAT after operation & 20 & 14.86850 & 12.95000 & 6.40 & 38.47 & 8.60 & 17.80 & 7.97 \\
\hline TAS before operation & 20 & 1.296500 & 1.290000 & 0.9200 & 1.8600 & 1.1450 & 1.3450 & 0.2245 \\
\hline TAS after operation & 20 & 1.536500 & 1.540000 & 0.92 & 2.600 & 1.315 & 1.725 & 0.38 \\
\hline
\end{tabular}

SOD - superoxide dismutase, GPX - glutathione peroxidase, CAT - catalase, TAS - total antioxidant status

Tab. V. Statistical significance of the differences in preoperative enzymatic activity between the study group and the control group

\begin{tabular}{ll} 
Variable & $p$ \\
\hline Preoperative SOD \& postoperative SOD & 0.244280 \\
\hline Preoperative GPX \& postoperative GPX & 0.934831 \\
\hline Preoperative CAT \& postoperative CAT & 0.000158 \\
\hline Preoperative TAS \& postoperative TAS & 0.000241 \\
\hline
\end{tabular}

TNF- $\alpha$-cytokine, which contributes to the spread of inflammatory processes in the airway epithelium [8]. Reactive oxygen or nitrogen species (ROS, RNS) in the respiratory system increase the production of pulmonary inflammation mediators and initiate or promote the mechanisms of carcinogenesis. Increased oxidant production has been revealed in smokers and patients with lung cancer in many previous publications $[9,10]$.

Free radicals are reactive compounds that have one or more unpaired electrons in their valence shell. ROS are produced in cellular sites by electron transfer reactions through enzymatic and non-enzymatic processes. The main sources of ROS are mitochondria, cytochrome P450, and peroxisomes $[8,11]$. Under physiological conditions there takes place constant production of ROS and RNS, which play an important role as secondary messengers in metabolic processes. At higher concentrations, free radicals and ROS/RNS are hazardous to living organisms. An excessive or sustained increase in ROS production can, if not balanced by antioxidant enzymes and non-enzymatic cellular antioxidant defenses, cause oxidative damage to all major
Tab. VI. Statistical significance of the differences in postoperative enzymatic activity between the study group and the control group

\begin{tabular}{lc} 
Variable & $p$ \\
Preoperative SOD \& postoperative SOD & 0.406495 \\
\hline Preoperative GPX \& postoperative GPX & 0.379098 \\
\hline Preoperative CAT \& postoperative CAT & 0.151752 \\
\hline Preoperative TAS \& postoperative TAS & 0.435339 \\
\hline
\end{tabular}

Tab. VII. Statistical significance of the differences between the preoperative and postoperative enzymatic activity in the study group

\begin{tabular}{lc} 
Variable & $p$ \\
\hline Preoperative SOD \& postoperative SOD & 0.822761 \\
\hline Preoperative GPX \& postoperative GPX & 0.040136 \\
\hline Preoperative CAT \& postoperative CAT & 0.025094 \\
\hline Preoperative TAS \& postoperative TAS & 0.030366 \\
\hline
\end{tabular}

cellular constituents (especially DNA). However, ROS can be either anticarcinogenic, by promoting apoptosis or inhibiting angiogenesis, or procarcinogenic, due to their ability to promote proliferation, angiogenesis and metastasis, and suppress apoptosis. ROS-induced DNA damage involves, for instance, single- or double-stranded DNA breaks, purine and/or pyrimidine modifications, as well as transcription and replication errors [11, 12].

All aerobic organisms have developed a series of defense mechanisms, including prevention mechanisms, re- 


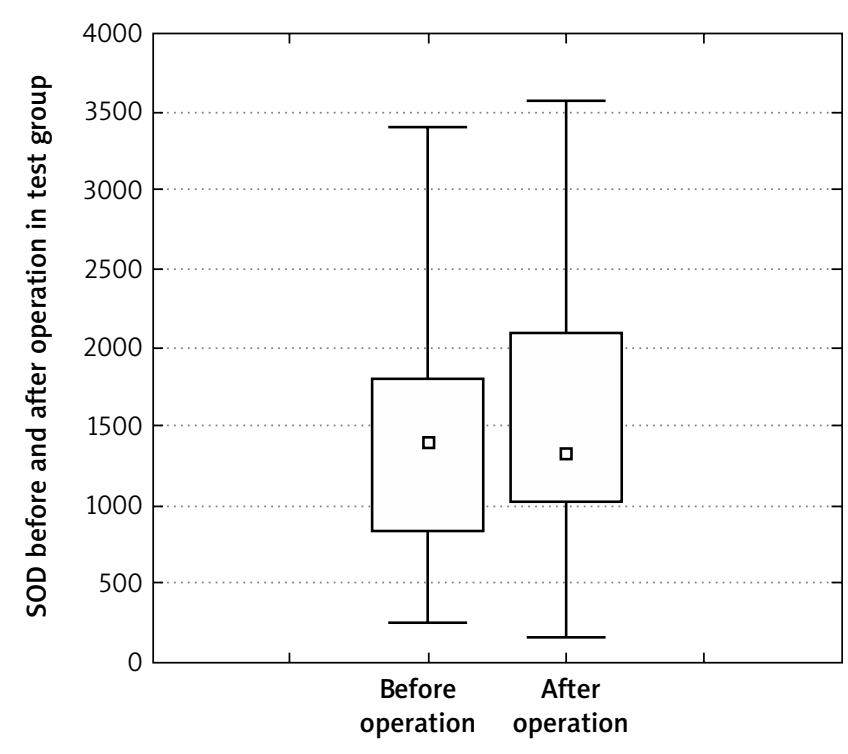

- Mediana $\square 25 \%-75 \% \quad$ IMin.-Maks

Fig. 5. Superoxide dismutase in the study group before and after surgery

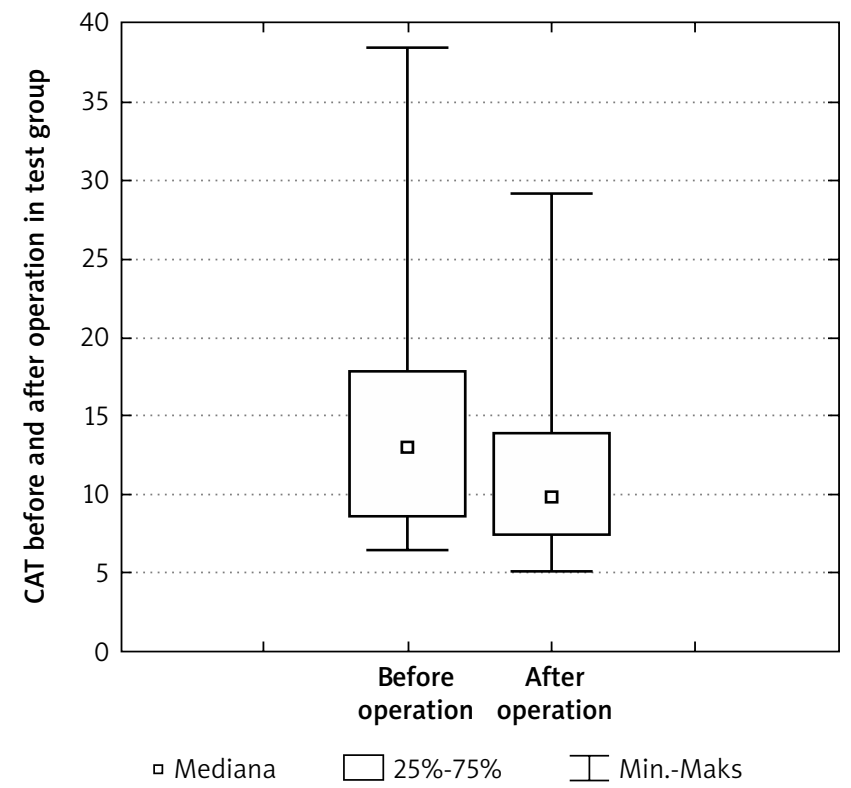

Fig. 7. Catalase in the study group before and after surgery

pair mechanisms, physical defenses, and antioxidant defenses. These antioxidants can intercept, scavenge, and neutralize radicals and their reactive intermediates. The most significant antioxidant enzymes are superoxide dismutase (SOD), occurring in 3 isoforms, catalase (CAT), and glutathione peroxidase (GPX) [12, 13].

Non-enzymatic antioxidants include vitamin $\mathrm{E}$, vitamins $\mathrm{C}$ and $\mathrm{A}$, selenium, transferrin, and lactoferrin. Antioxidants are mainly situated intracellularly [13]. The term "oxidative stress" is defined as the adverse condition resulting from an imbalance between cellular oxidants (mostly ROS and RNS) and antioxidants (enzymatic, such as CAT and SOD, and others).

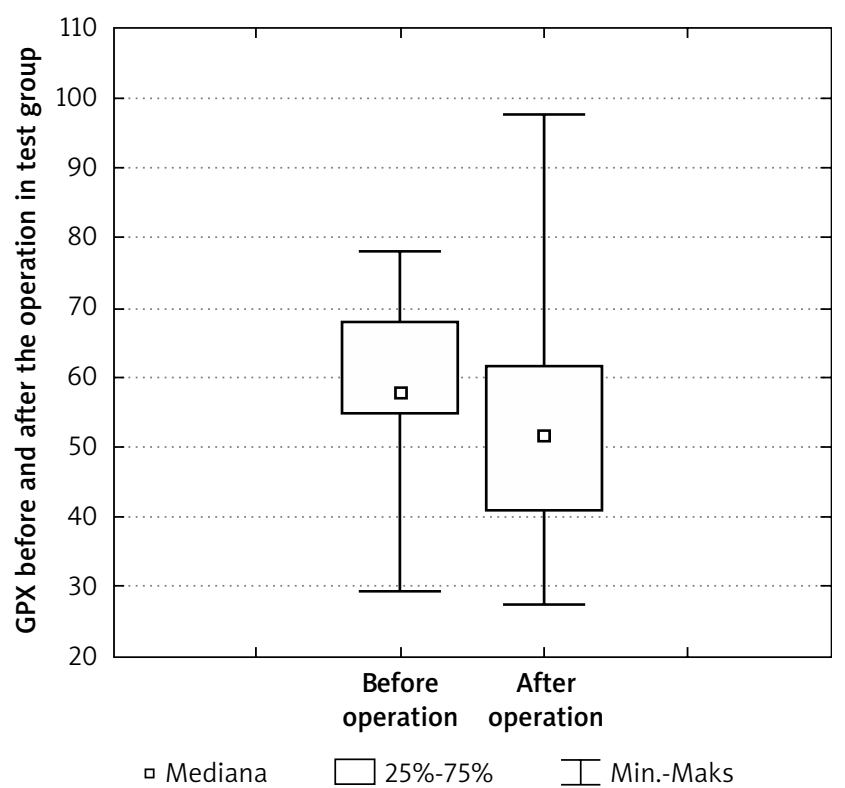

Fig. 6. Glutathione peroxidase in the study group before and after surgery

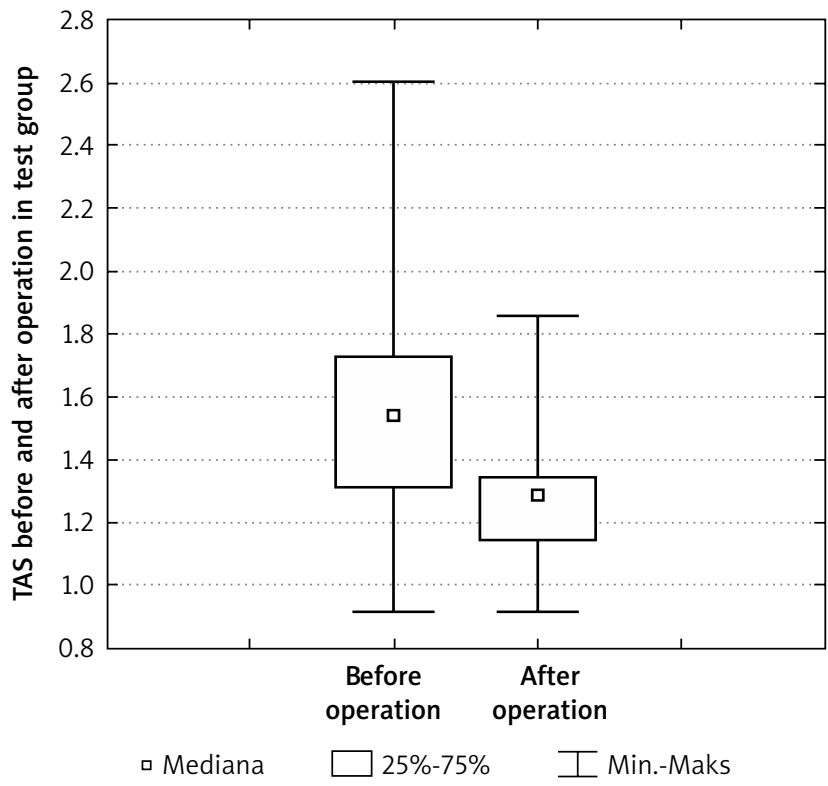

Fig. 8. Total antioxidant status in the study group before and after surgery

The present study demonstrates that the preoperative enzymatic activity in the study group was lower in comparison to the control group, but statistical significance was only found in the case of CAT activity and TAS. After the operation, we found statistically significant differences in the study group with respect to the activity of GPX and CAT as well as TAS; the activity of the enzymes increased. The activity of SOD increased as well, but this increase was not statistically significant. In comparison to the control group, the activity of antioxidative enzymes in patients with lung cancer was lower (both preoperative and postoperative levels), with the exception of the activity of GPX, whose level was decreased before and increased after the operation in 
the study group; these numbers, however, were not statistically significant. The alteration in systemic antioxidant profile was independent of age, height, and BMI parameters.

Our study showed that the enzymatic activity of antioxidative enzymes is lower in patients with lung cancer, which was also confirmed by other authors [12]. Similarly to other publications, we established that the surgical removal of lung cancer resulted in the augmentation of the total plasma antioxidant parameters; however, the activity was lower than in the control group, except for GPX [13, 14].

Our results confirmed that the activity of antioxidative enzymes is lower in patients with lung cancer, but further research is necessary to establish and investigate the significance of the systemic antioxidant activities as markers of disease status, especially in its early stages.

\section{Conclusions}

Oxidative mechanisms, when their function is impaired, may lead to chronic inflammation, which may in turn contribute to carcinogenesis. The results of this study show that patients with lung cancer exhibit lower activity of major antioxidative enzymes in comparison to controls; radical resection of the tumor contributes to increasing the activity of those enzymes, but it remains lower in comparison to the healthy population.

\section{Disclosure}

Authors report no conflict of interest.

\section{References}

1. Van Kampen EJ, Zijlstra WG. Standardization of hemoglobinometry II. The hemiglobincyanide method. Clin Chim Acta 1961; 6: 538-544.

2. Beers R, Sizer T. Spectrophotometric method for measuring the breakdown of hydrogen peroxide by catalase. J Biol Chem 1952; 195: 133-140.

3. Little C, O'Brian. Intracellular GSH-peroxidase with a lipid peroxide substrate. Biophys Res Commun 1968; 31: 145-150.

4. Misra HP, Ridovich J. The role superoxide anion in the autooxidation of epinephrine and a simple assay for the superoxide dismutases. J Biol Chem 1972; 247: 3170-3175.

5. Misthos P, Katsaragakis S, Theodorou D, Milingos N, Skottis I. The degree of oxidative stress is associated with major adverse effects after lung resection: a prospective study. Eur J Cardiothoracic Surg 2006; 29: 591-595.

6. Dzidkowska J, Wojciechowska U, Zatoński W. Cancer in Poland in 2011. Centrum Onkologii - Instytut im. Marie Skłodowskiej-Curie, Warszawa 2013.

7. Valavanidis A, Vlachogianni T, Fiotakis K, Loridas S. Pulmonary oxidative stress, inflammation and cancer: respirable particulate matter, fibrous dust and ozone as major causes of lung carcinogenesis through reactive oxygen species mechanisms. Int J Environ Res Public Health 2013; 10: 3886-3907.

8. Esme H, Cemek M, Sezer M, Saglam H, Demir A, Melek H, Unlu M. High levels of oxidative stress in patients with advanced lung cancer. Respirology 2008; 13: 112-116.

9. Barreiro E, Fermoselle C, Mateu-Jimenz M, Sánchez-Font A, Pijuan L, Gea J, Curull V. Oxidative stress and inflammation in the normal airways and blood of patients with lung cancer and COPD. Free Radic Biol Med 2013; 65: 859-871.

10. Filaire E, Dupuis C, Galvaing G, Aubreton S, Laurent H, Richard R, Filaire M. Lung cancer: what are the links with oxidative stress, physical activity and nutrition. Lung Cancer 2013; 82: 383-389.

11. Klimczak A, Kubiak K, Malinowska K, Dziki Ł. Activity of selected antioxidant enzymes examination in people with colorectal cancer. Pol Merkur Lekarski 2009; 162: 470-473.

12. Cobanoglu U, Demir H, Duran M, Şehitogullari A, Mergan D, Demir C. Erythrocyte catalase and carbonic anhydrase activities in lung cancer. Asian Pacific J Cancer Prev 2010; 11: 1377-1382.

13. Ho JC, Chan-Yeung SP, Ho SP, Mak JC, Ip MS, Ooi GC, Wong MP, Tsang KW, Lam WK. Disturbance of systemic antioxidant profile in nonsmall cell lung carcinoma. Eur Respir J 2007; 29: 273-278. 